Shakespeare

\title{
Shakespeare's Lost Playhouse: Eleven Days at Newington Butts
}

\section{Elizabeth E. Tavares}

To cite this article: Elizabeth E. Tavares (2018): Shakespeare's Lost Playhouse: Eleven Days at Newington Butts, Shakespeare, DOI: 10.1080/17450918.2018.1447988

To link to this article: https://doi.org/10.1080/17450918.2018.1447988

曲 Published online: 09 Apr 2018.

Submit your article to this journal ¿

Q View related articles $\square$

View Crossmark data \lceil 


\section{BOOK REVIEW}

\section{Shakespeare's Lost Playhouse: Eleven Days at Newington Butts, by Laurie Johnson, Routledge Studies in Shakespeare, London and New York, Routledge, 2017, xii + 214 pp., £105 (hardback), ISBN 978-1-138-29633-6}

What if the theatre industry that made someone like William Shakespeare possible was predicated on collaboration rather than individual endeavour? Of the many necessary explorations conducted and questions posed by Laurie Johnson in his recent monograph, Shakespeare's Lost Playhouse, this may be the most surprising. This necessary and long-overdue examination of the Playhouse that was located in Newington Butts, about a mile south of the River Thames and just outside the London city boundary, intervenes in three major ways. First, it literally and figuratively expands the map of where playing took place in London during the late sixteenth and early seventeenth centuries. Second, it provides a framework, supported by manuscript, archaeological and literary attestations, for analysing the work of playing companies outside the proverbial season. Third, it rhetorically places early professional plays presumed to be blockbusters due to their curricular primacy such as The Jew of Malta, Titus Andronicus, The Taming of the Shrew and Hamlet - alongside less-canonical and even "lost" plays, situating works associated with Shakespeare within a larger financial context.

The records of the 11 days of playing at Newington Butts are interesting by virtue of the fact that they mark the first time the Lord Chamberlain's name was associated with a playing troupe. More tantalising, however, is that the entry and orthography in Philip Henslowe's diary of accounts suggests two troupes combined forces in a dedicated playing venue: "In the name of god A men be-gininge at newing / ton my Lord Admeralle men \& my Lorde chamberlain / men As ffolowethe 1594 " (4). Not to be dissuaded from the endeavour by the ostensible dearth of evidence like his forebears, Johnson uses the archive available as a means to test theatre history's methodology and interrogative tools to see what they can illuminate given the circumstances. Each of the five chapters is organised around a documentary, literary or archaeological fact to address the archive as it stands rather than to build a narrative we might wish it suggested.

In his review of the current scholarship on the venue, playing companies and other personnel who may have tracked at Newington, the first chapter establishes the historiographical and ideological reasons why a "zone of exclusion" surfaced, encompassing Shoreditch and Bankside venues in the history of mapping the business of playing, but not the more southern communities of early modern London. Of especial interest for literary scholars is the discussion of the ways in which the "Newington conceit" - a particularly bad (or good, depending on your disposition) pun that remained in circulation well beyond the life of the Playhouse - operated as an index of the venue's "importance in the longer cultural memory of the playing community" (43).

Chapters two and three present new evidence about the affordances of the Playhouse's literal place on the map, including identifying the likely location of its remains. By establishing that it was built around the same time as the Theatre in 1575-76 (a venue about which it has been assumed the construction and origin was novel and without comparison but for the earlier Red Lion, built in 1567), Johnson challenges the traditional genealogy of theatre architecture in the city. Johnson undergoes the meticulous labour of examining civic documents to argue that, aside from being at a crucial trade junction as well as outside certain jurisdictions for bad behaviour, the venue was located at the highest point on the flood plain. This location demonstrates both bureaucratic and environmental savvy on the part of its builders in a time when western Europe was experiencing radical weather fluctuations in the midst of what Brian Fagan has termed a "little ice age". Chapter three 
shifts from the affordances of the region to that of the property itself, including size and shape as compared with its peers.

From a biographical standpoint, chapters four and five make the compelling case that the boards of the Playhouse gave witness to Richard Burbage and William Kempe, although not at the same time. For the disciplines of repertory studies and theatre history, however, the more important implications pertain to how critics discuss the mechanics of patronage and the quality of player affiliations when company genealogies are understood as fluid and that the guild model on which they were predicated invited rather than eschewed collegiality. To test this fluidity, Johnson examines, in subsections, the relevant archival history for each play performed to delineate what role it may have served in the context of a company's collected repertory. For example, one particular "clump" of plays from this repertorial set, putting Cutlack alongside Hamlet, suggests a thematic concern with "prospects for England's future through depictions of AngloDanish relations steeped in the deep past of the legends of both countries" (174). That never again would such a pairing of plays on a Danish theme be attempted by either company suggests that this momentary alignment fell flat or, perhaps, that thematic curation in the way in which we have become accustomed (i.e. the single-run model of contemporary theatre) was not financially viable for early moderns.

From a methodological standpoint, Johnson participates in current, dynamic conversation on the study of "lost" plays - play-texts we know to have been staged by way of paratextual evidence but for which the performed text itself does not survive - as recently revitalised by Roslyn Knutson, David McInnis, Matthew Steggle and others. Never does the conversation veer into intangible metrics of "influence", "popularity", or the "duopoly" model proffered by Andrew Gurr and hotly contested. Instead, Johnson relies on models privileging the labour of theatre-making and group-work obscured by impresario and other dichotomous frameworks. Interrogating the desire for cultural cohesion to which narratives of the theatre industry naturally tend, Johnson outlines what he calls the "Texas Sharp-Shooter Fallacy" as a paradigm for dealing with a lost archive that operated in sets. The fallacy, first identified by cancer researchers, refers to when a cluster of data is held to indicate a common causal origin, leading to the assumption that there is one common cause for the whole data set. The clustering suggests a trend that, in the case of early modern documents, is merely the product of a moment or aspect of an otherwise difficult archive that happens to be well-preserved. With more than two-thirds of early modern plays we know to have been performed in London non-extant, that "bullseye" is a mirage. Instead, Johnson suggests the goal of such work should be to "embrace the potentially haphazard nature of data sets", what physicists refer to as stochastic, "that accrue around Elizabethan playhouses" (8). Thus, this book speaks on multiple registers, leveraging an erudite yet pockmarked archive against other kinds of literary-critical pay-offs.

Questions of proximity and duration have been a drag on concerted study of the Playhouse at Newington Butts. Shakespeare's Lost Playhouse demonstrates that a fortnight provides more than enough data to make sense of this venue, as well as to situate its substantial participation in the sixteenth-century theatre industry. On the one hand, Johnson traces the poetic conceits of "cruel/crewel" and "butt naked" as they circulated in the 1580s and 1590s to articulate the kind of experience one was purchasing at the Playhouse. On the other hand, through modern geolocation, contemporaneous description and theatre-historical spadework, he identifies the exact coordinates of what would have been the main point of entry into the Playhouse. In combining these strategies, Johnson has created a kind of Humphry Repton "Red Book", providing an overlay, laminating then and now, whereby we can see that the entry to the Playhouse would have been gained at the same location a modern shopper finds the Elephant and Castle market stalls. Aside from recovering its literal and cultural place, Shakespeare's Lost Playhouse provides compelling implications for how scholars talk about patronage, the "arrow-dynamics" of player affiliations and the shared cultural memory of the early modern play-going community. 
Elizabeth E. Tavares

Pacific University (2) etavares@pacificu.edu (ID http://orcid.org/0000-0001-9410-190X

(C) 2018 Elizabeth E. Tavares https://doi.org/10.1080/17450918.2018.1447988

(D) Check for updates 